\title{
ANTIOXIDANT AND ANTI-INFLAMMATORY PROPERTIES OF A FLAVONOID FRACTION FROM THE LEAVES OF VOACANGA AFRICANA
}

\author{
S. B. OLALEYE. ${ }^{*}$, J.M. OKE, A. K. ETU ${ }^{1}$, I. O. OMOTOSHO ${ }^{2}$. and R.A. ELEGBE ${ }^{1}$ \\ Departments of ${ }^{1}$ Physiology, and ${ }^{2}$ Medicine University of Ibadan, Ibadan, Nigeria. \\ E-mail address: Olaleye_ui@hotmail.com Tel: 08023255893
}

\begin{abstract}
Summary: In this study we used several models for evaluation of probable anti-inflammatory and antinociceptive effects of the flavonoid fraction of the leaves of Voacanga africana, using mice and rats. The extract (50 - 150mg/kg, p.o) inhibited, in a dose-related manner, carrageenan induced paw oedema in rats. The extract caused a significant inhibition of the cotton-pellet granuloma. Vascular permeability induced by acetic-acid in the peritoneum of the animals was equally inhibited. The extract also exhibited significant analgesic action in acetic acid- induced pain in mice. There was reduction of writhings induced by acetic acid. In the formalin test, the extract caused inhibition of the neurogenic (first phase) and inflammatory phase (second phase) of formalininduced pain. The extract also produced anti-nociception in the animals, as assessed by the tail flick, hot-plate and limb-withdrawal tests. These findings suggest that the leaf extract of Voacanga africana has potent antiimfiammatory and anti-nociceptive action.
\end{abstract}

Key Words: Voacanga africana; anti-inflammatory and anti-nociceptive activities.

\section{Introduction}

Voacanga africana stept. ex Eliot (Apocynaceae) is a plant found in the understorey of forests. It is widely distributed from Senegal to Sudan and Nigeria to Angola and Zaire within the Africa region. An extracts from this plant have wide application in traditional African medicine. For example, in Nigeria, it is used for washing sores. A root decoction is given by mouth to women in Senegal to ward off the untoward consequences of premature or precipitant parturition. The same prescription is used for painful hernia (Thomas and Biermann, 1968)). There is abundant white latex in the bark and other parts. The latex is applied to wounds in Senegal (Kerharo and Adams, 1963) and into a carious tooth in Nigeria (and Adams, 1974).

However, due to the lack of information on the biological activity of Voacanga africana, we carried out studies using various models in an attempt to determine the character of any pharmacologically active ingredient of a simple methanol extract of Voacanga africana. These studies on the antiinflammatory and anti-nociceptive activities of the plant extract also aim to justify the folkioric use of this plant.

\section{Materials and Methods \\ Animals}

All animals (Rats, Weighing between 170$230 \mathrm{gm}$, mice weighing between 20-28gm) of male sex used for this studies were bred and housed in the pre-clinical Animal House,
College of Medicine. University of Ibadan. Ibadan. The animals were kept in a photo period-controlled environment (12 hours light -dark cycle). All the animals were kept in cages with solid floors covered with wood shavings, and there were given food and water ad libitum.

Preparation of the plant extract

Leaves of Voacanga africana tree situated at the premises of the forestry Research Institute of Nigeria (FRIN), Ibadan, Nigeria, were used throughout the study. The plant material was collected in the month of June and was authenticated and the specimens deposited in the Herbarium Forestry Research Institute of Nigeria, Ibadan, Nigeria (FHI106057).

The fresh leaves were air-dried, powdered (250g) and extracted with 95\% methanol for 5 days. The extract was filtered and the solvent removed via air drying. The yield was $9.75 \%$ $(\mathrm{w} / \mathrm{w})$.

1g of extract was subjected to column chromatography (column $40 \mathrm{~cm}$ long) on silica gel (70 - 230 mesh) usingn-hexane and EtOAc (4). $10 \mathrm{ml}$ fractions were collected and the elution of the flavanoids monitored by TLC using EtOAc (1:1) as the developing solvent. The plates were sprayed with $\mathrm{AlCl}_{3}$ in $95 \%$ EtOH (Krebs et al,1969). The flavanoids were revealed by UV light (254 and 365nm). 
Free radical scavenging activity

This was determined using the DPPH method (Ohinishi et al, 1994; Oke and Hamburger, 2002). Briefly, 0.1mM ethanol DPPH (Diphenyl-Picryl-hydraxyl) solution was added to different concentrations of the extract with gentle shaking. Triplicate measurements of the optical density change was done 10 minutes later with a spectronic-20 spectrophotometer at $517 \mathrm{~nm}$. The scavenging activity was measured as the decrease in absorbance of the samples versus DPPH standard solution. The results were expressed as percentage activity and mean inhibitory concentrations $\left(\mathrm{IC}_{50}\right)$ calculated using the logarithmic method of Litchfield and Wilcoxon (1949).

\section{Anti-inflammatory activity \\ Carrageenan-Induced Paw Oedema In Rats}

Acute inflammation in albino rats (10-12 weeks old) weighing 170-230gm was produced according to the method described by Winter et al (1962). An injection was made of $0.1 \mathrm{ml} 1 \%$ carrageenan on the sub-plantar surface of the right hind-paw of rats which had been fasted for 12 hours. Oedema was assessed for 3 hours, at $30-\mathrm{mm}$ intervals after administration of the extract, in terms of an increase in circumference of the carrageenan injected paw compared to the non-injected one. Animals were given agents under test orally at doses of 50,100 and $150 \mathrm{mg} / \mathrm{kg}$ (in $0.2 \mathrm{ml}$ ) of the extract one hour before carrageen injection.

At the same time, the control received $0.2 \mathrm{~m} 1$ normal saline and the reference group received $5 \mathrm{mg} / \mathrm{kg}$ (in $2 \mathrm{ml}$ ) indomethacin orally. Measurement of paw size was carried out by wrapping a piece of cotton thread round the paw and measuring the circumference with a metre rule .

The inhibitory activity was calculated according to the following formula:

Percentage Inhibition $=\left(\mathrm{C}_{\mathrm{t}}-\mathrm{C}_{0}\right)_{\text {control }}-\left(\mathrm{C}_{t}\right.$ $\left.=\mathrm{C}_{0}\right)_{\text {treated }}$

$$
\left(\mathrm{C}_{\mathrm{t}}-\mathrm{C}_{\mathrm{o}}\right)_{\text {Control }}
$$

where $C_{t}=$ Linear circumference of paw after carrageenan injection.

and $\quad \mathrm{C}_{\mathrm{o}}=$ Linear Circumference of paw before carrageenan injection

The inhibitory values at 3 hours, representing peak oedema are adopted as a measure of effect.

\section{Cotton Pellet Granuloma in rats}

The method described by Mossa et al (1995) was followed. A sterilized Cotton pellet weighing $20 \mathrm{mg}$ was introduced subcutaneously in the groin region of the rats. They were treated orally with 50,100 and 150 $\mathrm{mg} / \mathrm{kg}$ (in $0.2 \mathrm{ml}$ ) of the extract for 4 consecutive days. Animals in the control group received saline $(10 \mathrm{ml} / \mathrm{kg})$. Indomethacin $(5 \mathrm{mg} / \mathrm{kg})$ was given to animals in the reference group. On the fifth day, the animals were killed with chloroform, the pellets removed, freed from extraneous tissue and dried overnight and weighed.

\section{Acetic Acid-Induced Vascular Permeability}

The method of Whittle (1964) was used. One hour after oral administration of the extract at doses of 50, 150 and $150 \mathrm{mg} / \mathrm{kg}$ rats were injected with $0.25 \mathrm{ml}$ of $1 \%$ solution acetic acid intraperitoneally. Indomethacin $(5 \mathrm{mg} / \mathrm{kg})$ served as the reference drug, while animals in the control group received saline $(1 \mathrm{ml} / \mathrm{kg})$. Immediately after administration, $10 \mathrm{ml} / \mathrm{kg}$ of $10 \%(\mathrm{w} / \mathrm{v})$ Evan's blue was injected intravenously through the tail vein. Thirty minutes after Evan's blue injection, the rats were killed and the viscera exposed. The abdominal wall and the viscera irrigated with distilled water over a petri dish. The exudate was then filtered and made up to $10 \mathrm{mI}$. The dye leaking out into the peritoneal cavity was measured spectrophotometrically using visible spectra at $610 \mathrm{~nm}$.

\section{Analgesic Activity \\ Formalin-Induced Paw-Oedema}

The method of Hunskaar and Hole (1987) was used. 20ul of 3\% formalin was injected into the dorsal surface of the right hind paw of mice one hour after 50,100 and $150 \mathrm{mg} / \mathrm{kg}$ of extract were orally administered to the animals. Control animals received $10 \mathrm{ml} / \mathrm{kg}$ normal saline while $5 \mathrm{mg} / \mathrm{kg}$ indomethacin was administered orally to animals in the reference group. The test was carried out in a transparent plastic chamber of $33 \mathrm{~cm}$ by $21 \mathrm{~cm}$ by $17 \mathrm{~cm}$ with a mirror placed on the floor of the chamber, so as to have an obstructed view of the paws. The rats were placed in the chamber one at a time for 5 minutes prior to the formalin injection. This was done to allow them to explore the chamber and get familiar with it. The amount of time spent licking the injected paw was timed with a stop clock and was considered as indicative of pain.

The initial nociceptive scores normally peaked 5 minutes after formalin injection (first phase) and 15-30 minutes after formalin injection (second phase), representing the tonic and inflammatory responses, respectively. 


\section{Acetic Acid-Induced Writhing Test}

This method was based on that described by Santos et al (1994). Male albino mice weighing $20-28$ gm were divided into groups. Agents under test were administered through the intraperitoneal route 45 minutes before intraperitoneal injection of acetic acid $(0.6 \%)$ solution in distilled water at a dose of $10 \mathrm{ml} / \mathrm{kg}$. Control animals received a similar volume of $0.9 \% \mathrm{NaCl}(10 \mathrm{mI} / \mathrm{kg})$. Immediately after administering the acetic acid, the number $\%$ Inhibition $=$ of writhings and stretchings (a syndrome, characterized by a wave of contraction of the abdominal muscle together with a stretching of the hind-limbs) occurring between 5 and 15 minutes were counted. A reduction in the writhing number as compared to the control group was considered as evidence for the presence of analgesia, which was expressed as percent inhibition of writhings.

Acetylsalicylic acid $(250 \mathrm{mg} / \mathrm{kg})$ treated group served as a positive control. Data were calculated according to the following formula:

Mean number of writhings (Control) - Mean number of writhings (Treated) x 100 Mean number of writhings ( $\underline{\text { Control) }}$

\section{Hot-Plate Test}

Male albino mice weighing $20-28$ gm, were used. They were divided into groups and agents under test were administered orally. One hour later, the mice were placed on top of hot-plate of $55 \pm 0.7^{\circ} \mathrm{C}$. The time (s) between placement and jumping was recorded as response latency. The reaction time was recorded for control mice and for animals pretreated with the extracts of the plants.

Drugs

The drugs used were; Carrageenan (marine Colloids inc.), formalin, acetic acid, naloxone hydrochloride (Dupont, Garden City, USA) indomethacin (MSD, Canada), acetylsalicylic acid, pentazocine (Morphine analogue), and plant extracts. All other reagents used were of a high grade in purity. All drugs and extracts were dissolved in $0.9 \%$ $\mathrm{NaCl}$ solution just before use.

\section{Statistical Analysis}

Results are expressed as mean \pm standard error of the mean where ' $n$ ' is the number of observations in the group. Where applicable, comparisons between groups were made using students ' $t$ ' test. The difference between the groups is taken to be significant when $\mathrm{P}<$ 0.05 .

\section{Results \\ Radical Scavenging Effect}

At the highest concentration $(200 \mu \mathrm{g} / \mathrm{ml})$ of the extract of Voacanga Africana, the percentage decrease in DPPH absorbance was $63.62 \%$ (Table 1). On the other hand, the extract produced a percentage decrease in DPPH absorbance of $25.3 \%$ at the lowest concentration used $(10 \mu \mathrm{g} / \mathrm{ml})$. The mean inhibiting concentrations $\left(\mathrm{IC}_{50}\right)$, was $77.80 \mu \mathrm{g} / \mathrm{ml}$

Table 1 Antioxidant activity of flavonoid fraction from Voacanga africana leaf

\begin{tabular}{ccc}
\hline $\begin{array}{c}\text { Concentration of } \\
\text { flavonoid fraction }\end{array}$ & $\begin{array}{c}\text { \% decrease in } \\
\text { absorbance of DPPH }\end{array}$ & IC $_{50}(\mu \mathrm{g} / \mathrm{ml})$ \\
\hline $200 \mu \mathrm{g} / \mathrm{ml}$ & 63.62 & \\
$100 \mu \mathrm{g} / \mathrm{ml}$ & 58.42 & $77.80 \mu \mathrm{g} / \mathrm{ml}$ \\
$50 \mu \mathrm{g} / \mathrm{ml}$ & 39.32 & \\
$25 \mu \mathrm{g} / \mathrm{ml}$ & 30.25 & \\
$12.5 \mu \mathrm{g} / \mathrm{ml}$ & 25.3 \\
\hline
\end{tabular}

\section{Anti-Inflammatory Studies}

Carrageenan-Induced Paw Oedema In Rats

Carrageenan-induced rat paw oedema was inhibited by oral (intragastric) pre treatment with the extract $(50-150 \mathrm{mg} / \mathrm{kg}$, p.o). the inhibitory effect was most pronounced with
$150 \mathrm{mg} / \mathrm{kg}$ dose (Table 2) Cotton-Pellet Granuloma in Rats

The extract at all doses $(50-150 \mathrm{mg} / . \mathrm{kg}$, p.o) were found to reduce granuloma tissue formation in the animals in a dose-related manner (Table 3) 
Table 2: Effect of methanol extract of Voacanga africana leaves on carrageena induced paw oedema in rats.

\begin{tabular}{cccc}
\hline Group (n=10) & $\begin{array}{c}\text { Dose }(\mathrm{mg} / \mathrm{kg}) \\
\text { orally }\end{array}$ & Mean paw size (cm) & Inhibition (\%) \\
\hline Control (saline) & - & $3.54 \pm 0.22$ & - \\
V. Africana & 50 & $2.80 \pm 0.74^{*}$ & 62.6 \\
V. Africana & 100 & $2.60 \pm 0.32^{*}$ & 75.8 \\
V. Africana & 150 & $2.46 \pm 0.22^{*}$ & 87 \\
Indomethacin & 5 & $2.65 \pm 0.35^{*}$ & 71.7 \\
\hline
\end{tabular}

Each group represents the mean \pm S.E.M. of n., * $P<0.05$ compared with control values.

Table 3: Effect of methanol extract of Voacanga africana leaves on cotton pellet granulonia in rats.

\begin{tabular}{cccc}
\hline $\begin{array}{c}\text { GROUP } \\
(\mathrm{n}=10)\end{array}$ & $\begin{array}{c}\text { Dose } \\
(\mathrm{mg} / \mathrm{kg}) \\
\text { orally }\end{array}$ & $\begin{array}{c}\text { Mean increase in } \\
\text { weight of pellets } \\
(\mathrm{mg})\end{array}$ & Inhibition (\%) \\
\hline Control (saline) & - & $49.40 \pm 0.26$ & - \\
V. Africana & 50 & $36.75 \pm 0.30^{*}$ & 19.5 \\
V. Africana & 100 & $30.10 \pm 0.22 *$ & 39 \\
V. Africana & 150 & $24.35 \pm 0.20^{*}$ & 50.7 \\
Indomethacin & 5 & $22.40 \pm 0.34 *$ & 54.7 \\
\hline
\end{tabular}

Each group represents the mean \pm SEM. of ten experiments.

$* P<0.05$ compared with control values.

Acetic acid - induced vascular permeability

There was reduction in degree of peritoneal.inflammation produced by acetic acid in the animals, by extract of Voacanga Africana. The quantity of dye leakage was significantly reduced by all doses of the extracts investigated (50- $150 \mathrm{mg} / \mathrm{kg}$, p.o) (Table 4)

\section{Analgesic Study \\ Formalin-Induced Paw licking in Mice}

In the formalin test, the extracts of Voacanga africana (50 - $150 \mathrm{mg} / \mathrm{kg}$, p. o) caused marked and dose-related inhibition against both phases of formalin - induced pain (Figure 1). The inhibitory effect was most pronounced with $150 \mathrm{mg} / \mathrm{kg}$ dose.

\section{Acetic acid-induced Writhing in Mice}

Results shown in Table 5 indicated that oral (intragastric administration of the extracts of Voacanga africana (50 -150 mg/kg, p.o) were effective in reducing the number of writhing and stretching movements induced by intraperitoneally injected acetic acid. This anti nociceptive effect of the extracts was most pronounced at dose of $150 \mathrm{mg} / \mathrm{kg}$.

\section{Hot-Plate Test}

Figure 2 shows the response of mice to hot-plate test. The reaction time was increased in mice treated with extracts of Vocanga africana, when administered orally at doses ranging $50-150 \mathrm{mg} / \mathrm{kg}$. 
Antioxidant properties of V. africana

Table 4: Effect of methanol extract of Voacanga africana leaves on acetic acid-induced vascular permeability in rats.

\begin{tabular}{cccc}
\hline $\begin{array}{c}\text { GROUP } \\
\mathrm{n}=10\end{array}$ & $\begin{array}{c}\text { Dose (mg/kg) } \\
\text { orally }\end{array}$ & $\begin{array}{c}\text { Mean increase in } \\
\text { weight of pellets } \\
(\mathrm{mg})\end{array}$ & $\begin{array}{c}\text { Inhibition } \\
(\%)\end{array}$ \\
\hline $\begin{array}{c}\text { Control } \\
\text { (saline) }\end{array}$ & - & $71.3 \pm 0.33$ & - \\
V. Africana & 50 & $41.10 \pm 0.28^{*}$ & 42.5 \\
V. Africana & 100 & $35.00 \pm 0.26^{*}$ & 50.9 \\
$\begin{array}{c}\text { V. Africana } \\
\begin{array}{c}\text { Indomethaci } \\
\mathrm{n}\end{array}\end{array}$ & 150 & $32.56 \pm 0.24^{*}$ & 54.3 \\
\hline
\end{tabular}

Each group represents the mean \pm SEM of ten experiments.

$* P<0.05$ compared with control values.

Table 5: Effect of methanol extract of Voacanga africana leaves on acetic acid-induced writhings in mice.

\begin{tabular}{cccc}
\hline $\begin{array}{c}\text { GROUP } \\
\mathrm{n}=10\end{array}$ & Dose $(\mathrm{mg} / \mathrm{kg})$ & $\begin{array}{c}\text { Mean number of } \\
\text { writhings }\end{array}$ & $\begin{array}{c}\text { Inhibition } \\
(\%)\end{array}$ \\
\hline $\begin{array}{c}\text { Control } \\
\text { (saline) }\end{array}$ & - & $40.00 \pm 0.51$ & - \\
V. Africana & 50 & $25.50 \pm 0.62^{*}$ & 36 \\
V. Africana & 100 & $19.80 \pm 0.42^{*}$ & 50.5 \\
V. Africana & 150 & $15.40 \pm 0.45^{*}$ & 61.5 \\
ASA & 250 & $11.70 \pm 0.47 *$ & 70.8 \\
\hline
\end{tabular}

Each group represents the mean \pm SEM of ten experiments.

$* P<0.05$ compared with control values. 
Figure 1: Effect of flavonoid fraction of the methanol extract of Voacanga africana leaves on formalininduced paw licking in mice. Each vertical line represents the S.E.M of 10 animals in each group.

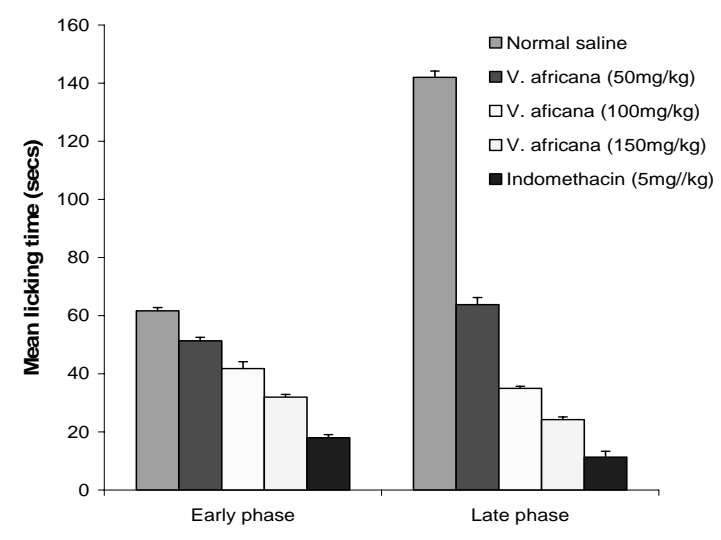

Figure 2: Effect of methanol extract of Voacanga africana leaves on hot-plate latency in mice.

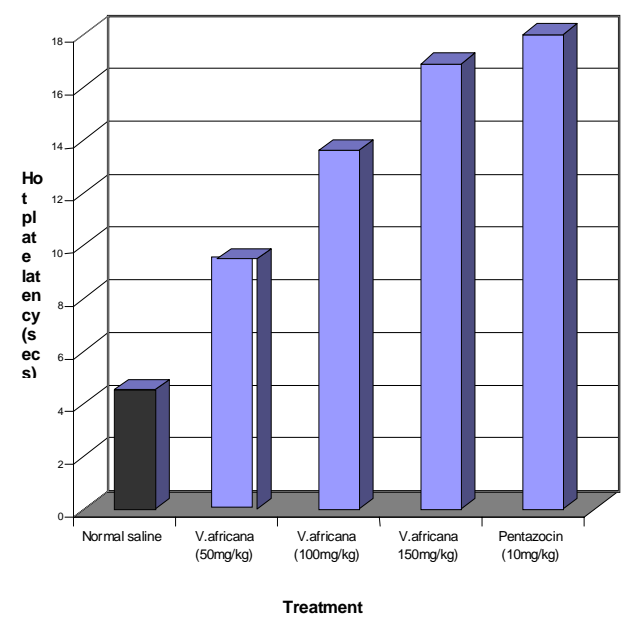

\section{Discussion}

The results of the present study suggest that the flavanoid fraction of the methanol extract of the leaves of Voacanga africana has significant antioxidant activity. The DPPH test provides information on the reactivity of test compounds with a stable free radical. Because of its odd electron, 2, 2diphenyl-picryl-hydrazyl radical (DPPH) gives a strong absorption band at $517 \mathrm{~nm}$ in visible spectroscopy (deep violet colour). As the electron becomes paired off in the presence of a free radical scavenger, the absorption varnishes, thus the resulting decolorization is stoictiometric with respect to the number of electrons taken up. Due to their polyphenols parentage, flavanoids are generally good scavengers of free radicals.

This study have also demonstrated that flavanoids of the extracts obtained from the leaves of Voacanga africana (Apocynaeceae) may be responsible for the anti-inflammatory activities of the crude extracts of the plant as earlier reported (Etu et al, 2000; 2001). The fraction, given intraperitoneally and orally (intragastric), exhibited potent and dose-related anti-inflammatory activity when analysed in several models of inflammation in rats. Oral administration of extracts caused an inhibition of carrageenan induced oedema assessed at 30 , 60, 90, 120, 150 and 180 minutes after subplantar injection of carrageenan. Carrageenan-induced rat paw oedema is a suitable test for evaluating anti-inflammatory drugs which has been frequently used to assess the anti oedematous effect of natural products. 
Dirosa et al (1971) earlier reported that carrageenan - induced inflammation is useful in detecting orally active anti-inflammatory agents. Vinegar et al (1969) reported that oedema formation due to carrageenan in the rat paw is a biphasic event. The initial phase is attributed to the release of histamine and serotonin (1971). The second phase of oedema is as a result of liberation of prostaglandins, lysosome, bradykinins, and protease (Vineger et al, 1969; Crunkhon and Meacock, 1971). Dirosa et al (1971) had earlier stated that the second phase is sensitive to most clinically active anti-inflammatory drugs.

In a test of more chronic inflammation, such as granuloma cotton pellet, the potency of the extracts was observed. The final dry weight of the cotton pellets correlates very well with the amount of granulomatous tissue (Single and Shidman, 1972). The extracts of Voacanga africana showed significant anti-inflammatory action in the cotton pellet test. This action showed that the extracts have the capability in reducing the synthesis of mucopolysaccharide and collagen, and the number of fibroblasts, which are natural proliferative events of granulation in tissue formation.

The anti-inflammatory action of Voacanga africana was also shown by its ability to reduce the vascular permeability by reduction of dye leakage into the peritoneal cavity by acetic acid in the animals studied.

The extracts of Voacanga africana also exhibited potent anti-nociceptive action against formalin and acetic acid - induced pain responses in mice. The formalin test in mice is a useful test for evaluating mild analgesics. The test employs an adequate painful stimulus, the animals show a spontaneous response and the test is sensitive to the commonly used analgesics. The pain stimulus is continuous rather than transient and may thus have semblance to some forms of clinical pain. The test has two different phases, reflecting different types of pain. The first phase reflects a direct effect of formalin on nociceptors (noninflammatory pain) whereas the second phase reflects inflammatory pain (Elizabetsky et al, 1995). In this study, extracts of Voacanga africana are capable of attenuating, in a doserelated fashion, both the neurogenic and the inflammatory phases of pain. This probably shows that the anti-nociceptive action of the extracts was mediated by both neurogenic and inflammatory mechanisms.

The extract shows high potency in inhibiting the inflammatory components of the formalin test. This is a typical characteristic of some cyclo-oxygenase inhibitors, which are effective in inhibiting only the last phase of the formalin-induced pain. However, these extract, at a higher dose of $150 \mathrm{mg} / \mathrm{kg}$ (p.o.) failed to abolish completely either of the phases associated with the formalin test. This suggests that part of this nociceptive response in the formalin test involves mediators that may be insensitive to active principles of Voacanga africana. It has been shown that the inflammatory pain associated with the second phase of the formalin test is accompanied by release of several inflammatory mediators (Hunskar et al, 1985; Abbott and Franklin, 1986; Murray et al, 1988; Chapman and Dickenson, 1992; Correa and Calixto, 1993).

The extract of Voacanga africana showed strong anti-nociceptive action in mice, by inhibiting the acetic acid-induced writhing. Acetic acid-induced writhing is a highly sensitive and useful test for analgesic screening. The extracts of Voacanga africana also exhibited strong anti-nociceptive actions in mice by increasing the latency period in the hot-plate test. These findings seem to, in part justify the folkloric use of this plant. Further studies are in progress in our laboratory to confirm the identity of the bioactive compounds responsible for these actions shown by the leaves of Voacanga africana.

\section{References}

Abbott, F.V. and Franklin, K. B. J. (1986). Non competitive antagonism of morphine an analgesic by diazapam in the formalin test. Pharmacol. Biochem. Behav. 24:319321.

Chapman, V. and Dickenson, A.H. (1992). The spinal and peripheral roles of bradykinin and prostaglandins in nociceptive processing in the rat. Eur. J. Pharmacol. 219: 427- 433.

Correar, C.R and Calixto, J. B. (1993) Evidence for participation of $\mathrm{Bl}$ and $\mathrm{B} 2$ Kinin receptors in formalin - induced nociecptive response in mouse. Br. J Pharmacol 110: 193- 198.

Crunkhon, P. and Mea cock, S.E.R. (1971) Mediators of the inflammation induced in the rat paw by carrageenan. Br. J. Pharmacol. 42:392 - 402.

Di Rosa, M; Giroud, J.P and Willoughby, D.A (1971). Studies of the acute inflammatoiy response induced in rats in different sites by carrageenan and turpentine. J. Pathol. 104: 15- 29.

Elisabetsky, E., Amador, T.A., Albuquerque, R.R, Nunes, D.S and Carvaiho, A. C.T (1995). Analgesic activities of psychotria 
colorate (Wild ex R. and S). Muel alkaloids. J. Ethnopharmacol. 48:77-83.

Etu A.K, Olaleye S.B, Oke J.M and Elegbe R.A (2000). A preliminary study on the anti-nociceptive properties of Voacanga africana leaf extracts. Abstract of proceedings of the $20^{\text {th }}$ Scientific conference of the Physiological Society of Nigeria. Nig. J. Physiol Sci. 16 (1 - 2)

Etu A.K, Olaleye S.B, Oke J.M and Elegbe R.A (2002). Antiinflammatory and Antinociceptive properties of aqueous extract of Voacanga africana leaf. Biosc. Res. Comm. 14 (In press)

Gonzales A. G, Aguiar Z. E, Grillo T.A, Luis J.G, Rivera A and Calle J (1991). Chromenes from Ageratum conyzoides. Phytochemistry 30: 1269 - 1271.

Hunskaar, S. and Hole, K. (1987). The formalin test in mice: dissociation between inflammatory and noninflammatory pain. Pain 30:103-114.

Hunskaar, S., Fasmar, 0.B and Hole, K, (1985) formalin test in mice: a useful technique for evaluating mild analgesics. $J$. Neurosci. Methods 14: 69- 76.

Kerharo, J and Adams J.G (1974) Ia pharmacopie senegaaire traditionelle, plants medicinles ete toxiques. Vog freres, paris

Kerharo, J. and Adams, J.G (1963) Deuxieme inventaire des plantes medicinnales et toxiques de Ia casarnance (Senegal). Ann. Pharm. France 21:773 -792.

Krebs K. G, Heuser D, Wimmer W (1969): Thin-layer Chromatography: Berlin, Heidelberg, New York, Springer-Verlag.

Litchfield J.T and Wilcoxon F (1949): A simplified method of evaluating doseeffect experiments. J. Pharmacol. Exp. Ther. 96: 99 -113

Mossa, J.S., Fadatullah S., Gala!, A .M and AlYahuya. M.A (1995). Pharmacological studies of Rhus retinorrhaea. Int. J. Pharmacognosy 33; 243 - 246.
Murray, C.W., Porreca, F. and Cowan, A (1988). Methodological refinements in the mouse paw formalin test an animal mode! of tonic pain. J. Pharmacol. Methods 20: 175- 186.

Ohinishi M, Morishita H, Iwahash H, Shizuo T, Yoshiaki S, Kimura M, Kido R (1994). Inhibitory effects of chlorogenic acids on linoleic acid, peroxidation and heamolysis. Phytochemistry 36: 579 - 583

Oke J.M and Hamburger M.O (2002): Screening Of Some Nigerian Medicinal Plants For Antioxidant Activity Using 2, 2, Diphenyl-Picryl-Hydrazyl Radical. African J. Biomedical. Res. 5: 77 - 79.

Santos, A.R.S., Valdir, C.F., Rosendo, A.Y. and Joao, B.C (1995). Further studies on the antinociceptive action of the hydroalcololic extracts from plants of the genus Phyllanthus. J. Pharm. Pharmacol. 47: 66-71.

Swingle, K.F and Shideman, F.E (1972). Phases of inflammatory response to subcutaneous implantation of cotton pellet and other modifications by certain antiinflammatory agents. J. Pharmacol. Exp. Ther. 183: 226-234.

Thomas, D.W and Bienmann,K (1968) The alkaloids of Voacanga africana, Lloydia 31:1- 8 .

Vinegar, R., Schreiber, W. and Hugo, R. (1969). Biphasic development of carrageenan oedema in rats. . $J$. Pharmacol. Exp. Ther. 166: 96-103.

Whittel, B.A. (1964). The use of changes in capillary permeability in mice to distinguish between narcotic and nonnarcotic analgesic. Br.J. Pharmacol. Chemotherapy 22: 246 -253.

Winter, C.A., Risley, E.A and Nuss, C.W. (1962). Carrageenan - induced oedema in hind paws of the rat as an assay for antiinflammatory drugs. Proc. Soc. Expt Biol. Med. 111:544-547.

Received: September 30, 2004

Accepted: December 6, 2004 